\title{
PEMILIHAN DAN PEMERTAHANAN BAHASA JAWA PADA KAUM PEREMPUAN PESISIR REMBANG
}

\author{
Suharyo \& Nurhayati \\ Universitas Diponegoro, Semarang \\ Email: haryo.sastra@gmail.com
}

\begin{abstract}
Abstrak
Pada masyarakat Jawa, pemilihan sebuah kode (bahasa/ragam) ditentukan oleh banyak faktor, misalnya: usia, jenis kelamin, derajat sosial, pangkat, tempat, diksi, dan ragam. Penelitian bertujuan menggali pemilihan dan pemertahanan bahasa Jawa oleh kaum perempuan pesisir di Rembang. Penelitian ini mengambil sampel Kecamatan Sulang, Desa Karangharjo Rembang untuk mewakili Rembang desa. Yang kedua Kecamatan Rembang Desa Leteh untuk mewakili Rembang kota dengan 79 responden dan 7 informan. Pengambilan data dilakukan melalui angket dan wawancara terstruktur dan mendalam. Data dianalsis secara kuantitatif untuk data yang diambil melalui angket dan kualitatif untuk data yang diperoleh dari wawncara. Hasilnya, (1) pemertahanan bahasa Jawa untuk masyarakat, khususnya perempuan Rembang bahasa Jawa (ngoko) cukup kuat (antara 48\% sampai dengan 60\%), (2) bahasa Indonesia sudah mulai masuk pada ranah rumah, (3) masyarakat Rembang tergolong masyarakat diglosik, (3) pada masyarakat Remang (khususnya kaum perempuannya) sedang terjadi pergeseran bahasa dari bahasa Jawa ke bahasa Indonesia, (4) jika bahasa Jawa ragam krama identik dengan kesantunan, maka masyarakat/kaum perempuan Rembang desa dinilai lebih santun daripada masayarakat Rembang kota. Adapun pola pemertahanan dilakukan melalui (a) pengguunaan bahasa sehari-hari di rumah meski sebagian besar menggunakan bahasa Jawa ragam ngoko, (b) melalui jalur pendidikan, (c) melalui jalur seni/budaya, (d) dan jalur keteladanan tokoh masyarakat, serta (e) dukungan pemerintah setempat melalui berbagai lomba tahunan.
\end{abstract}

Kata kunci: pemilihan bahasa, pemertahanan bahasa, bahasa Jawa, pola pemertahanan bahasa Jawa.

\section{THE SELECTION AND RETENTION OF JAVANESE BY COASTAL WOMEN IN REMBANG}

\begin{abstract}
In Javanese society, the choice of a code (language / variety) is determined by many factors, for example: age, gender, social status, rank, place, diction, and variety. This research aims to explore the selection and retention of Javanese by coastal women in Rembang. This study took a sample of Sulang Subdistrict, Karangharjo Rembang Village to represent Rembang village. The second is Rembang Subdistrict Leteh Village to represent Rembang City with 79 respondents and 7 informants. Data collection was carried out through structured and in-depth questionnaires and
\end{abstract}


interviews. Data are analyzed quantitatively for data taken through questionnaires and qualitatively for data obtained from interviews. As a result, (1) the retention of Javanese for the community, especially Javanese (Ngoko) women is quite strong (between 48\% and 60\%), (2) Indonesian has begun to enter the realm of houses, (3) the Rembang community belongs to the diglosik community, (3) in the Rembang community (especially women) there is a shift in language from Javanese to Indonesian, (4) if Javanese is diverse in etiquette with politeness, then the community / women of Rembang desa are considered to be more polite than the people of Rembang City. The pattern of detention is carried out through (a) the use of everyday language at home, although most use the Javanese variety of ngoko, (b) through education, (c) through art / culture, (d) and exemplary community leaders, and (e) local government support through various annual competitions.

Keyword: language selection, language retention, Javanese language, Javanese language retention patterns.

\section{PENDAHULUAN}

Meskipun pemilihan bahasa sudah sering diteliti oleh sejumlah pakar, tetap saja selalu menjadi kajian yang menarik. Sebab, bahasa dalam pandangan sosiolinguistik tidak bersifat monoton, statis, dan berada pada "ruang hampa" sosial. Sosiolinguistik memandang tidak ada satu pun bahasa/kode bersifat monolitik. Bahasa/kode selalu variatif karena -sebagaimana diungkapkan Fishman- bahwa pemilihan bahasa selalu mempertimbangkan dimensi siapa, apa, di mana, kapan, mengapa. Jadi, bahasa selalu dilihat dalam konteksnyadimasyarakatpenggunanya. Karenanyalah, pemilihan bahasa bersifat dinamis. Bahkan Fasold pernah mengatakan bahwa sosiolinguistik itu ada sebagai ilmu karena ada pemilihan bahasa.

Pemilihan bahasa (yang dilakukan oleh penutur dalam suatu masyarakat tutur) selalu mengimplikasikan adanya kedwibahasaan bahkan kemultibahasaan. Dari sinilah lalu, seorang penutur tersebut mengalami "dilema" ketika harus memilih salah satu kode (bahasa/dialek) sebagai wujud ekspresinya. Apalagi jika hal tersebut dihubungkan dengan masyarakat Jawa. Sebab, pada masyarakat Jawa, pemilihan sebuah kode (bahasa/ragam) ditentukan oleh banyak faktor, misalnya: usia, derajat sosial, pangkat, tempat, diksi, dan ragam. Ketika seorang penutur berusia lebih muda berkomunikasi dengan lawan bicara yang lebih tua (usianya), penutur tersebut "harus" hormat kepadanya dengan memilih kodebahasa Jawa ngoko alus atau krama madya, misalnya. Begitu juga jika menyangkut derajat sosial, penutur Jawa memiliki "kesadaran derajat sosial" (introspeksi diri) ketika berkomunikasi dengan seseorang yang derajat sosialnya lebih tinggi, yaitu, misalnya, menggunakan kode bahasa Jawa ragam krama atau krama inggil. Secara ringkas, kondisi dan kendala-kendala dalam pemilihan bahasa, khususnya pada masyarakat Jawa dirangkum dalam ungkapan "empan papan", yaitu kesadaran 
seseorang tentang siapa dirinnya, dari mana asalnya, dari golongan mana, pangkatnya, derajatnya sebagai bekal untuk memahami dirinya dan orang lain (dalam interkasi sosial) sehingga tidak salah.

Konsep "empan papan" pada masyarakat Jawa identik dengan konsep diglosia yang dikemukakan Fishman. Dalam konsep diglosia, terdapat konvensi sosial berupa penggunaan bahasa/kode sesuai fungsi dan perannya. Menurutnya, ada bahasa/ kode tertentu yang "tepat" pada situasi dan atau ativitas sosial tertentu. Domain/ranah tertentu. Misal, bahasa Indonesia "lebih tepat" digunakan pada domain pendidikan, domain pekerjaan, domain agama; sedangkan bahasa Jawa "lebih tepat" digunakan pada domain rumah, ketetanggan, dan persahabatan. Jika terjadi "pelanggaran" terhadap konvensi tersebut. Katakalanlah bahasa Indonesia digunakan di doman rumah, maka peristiwa/gejala tersebut menurut Fishman disebut sebagai "kebocoran" diglosia. Jika "kebocoran diglosia terus-menerus berulang dan berpola, maka kejadiaan berikutnya adalah terjadi pergeseran bahasa. Misal, dari bahasa Jawa bergeser ke bahasa Indonesia. Pada gilirannya, jika hal itu terus berlangsung dalam kurun waktu yang lama; dari satu generasi ke generasi berikutnya, maka akan terjadi kepunahan bahasa.

Kajian terhadap pemilihan, pergeseran, dan atau pemertahanan bahasa Jawa sudah cukup banyak dilakukan. Hasil penelitian Suharyo (2017; 2018) misalnya, menyebutkan bahwa para generasi muda baik Jawa maupun non-Jawa telah mengalami pergeseran dalam bebahasa dari bahasa daerah ke bahasa Indonnesia. Bahkan yang lebih memrihatinkan mereka kelak ketika sudah menikah akan memilih bahasa Indonesia sebagai bahasa pertamanya bagi anaknya. Penelitian Hadiyati (2013) juga menengarai hal yang sama, yaitu generasi muda Jawa sudah mulai meninggalkan bahasa Jawa sebagai bahasa ibunya/bahasa pertamanya. Hasil penelitian Syaifudin (2008) menyebutkan pula bahwa telah terjadi pergeseran bahasa, yaitu dari bahasa Jawa ke bahasa Sunda pada masyarakat Losari (daerah perbatasan Jawa Tengah-Jawa Barat). Meskipun demikian, menurutnya bahasa Jawa secara dominan digunakan pada ranah rumah. Gambaran "persaingan" antara bahasa daerah (Jawa) sebagai bahasa minoritas dan bahasa Indonesia (sebagai bahasa mayoritas) terjadi pula di Australia, seperti digambarkan oleh Mostefa Abdelhadi(2018) antarabahasa Arab (bahasa penduduk imigran) dan bahasa Inggris (penduduk Australia).

Hasil penelitian Syaifudin (2008) menunjukkan bahwa terjadinya pergeseran (dari bahasa Jawa dan ke bahasa Sunda) ditengarahi sebagai upaya adaptasi atau integrasi sosial masyarakat perbatasan sebagaimana temuan penelitian Mat Awali, Norsimah et.al. (2013), yaitu pada masyarakat perbatasan Malaysia-Thailand. Hasil penelitian Yusmawati, et.al. (2018) pada masyarakat Tionghoa di Langsa (Aceh) ditemukan pola pemilihan bahasa antara bahasa Aceh dan bahasa Indonesia. Pada masyarakat tipe pertama (yang memilih bahasa Aceh) beralasan untuk adaptasi dan integrasi sosial, sedangkan pada masyarakat tipe kedua (yang memilih bahasa Indonesia) dengan alasan agar anak-anaknya tidak 
mendapat kesulitan ketika bersekolah kelak.

Dari kutipan hasil penelitian yang dipaparkan di atas menunjukkan adanya dua pola masyarakat tutur, yaitu (a) yang masih mempertahankan bahasa daerah/Jawa dan (b) yang telah menggeser dari bahasa daerah/ibu ke bahasa lainnya. Dari temuan-temuan penelitian di atas menunjukkan adanya faktor penguat dan pelemah terjadinya pemertahanan dan atau pergeseran bahasa. Faktor-faktor penguat terjadinya pemertahanan bahasa, di atanranya adalah (a) masih digunakannya BD (bahasa daerah) di ranah/domain rumah, ketetanggaan, (b) masih kuatnya pengalaihan $\mathrm{BD}$ ke generasi selanjutnya, (c) faktor agama, (d) faktor in- tegrasi sosial, (e) konsentrasi geografi, (f) intensitas penggunaan BD pada domain sosial oleh kalangan generasi muda. Sementara, faktor pelemah terjadinya pemertahanan bahasa antara lain (1) berkurangnya penggunaan $\mathrm{BD}$ pada ranah rumah, ketetanggaan, (b) tidak ada pengalihan/ transfer BD ke generasi selanjutnya, (c) keengganan generasi muda untuk memilih $\mathrm{BD}$ karena dianggap kuno, (d) masyarakat tutur memandang bahasa Indonesia dan apalagi bahasa Inggris lebih bergengsi daripada BD.

Salah satu penyebab melemahnya daya tahan hidup $\mathrm{BD}$ diduga, salah satunya, disebabkan oleh pendidikan yang "tidak ramah" terhadap penggunaan $\mathrm{BD} /$ bahasa lokal sebagai pengantar pembelajaran di sekolah. Hal itu, dapat dilihat, misalnya, pada kurikulum yang hanya menjadikan BD sebagai muatan lokal. Di samping faktor pendidikan, faktor lainnya adalah kebijakan politik bahasa pemerintah. Lihatlah, misalnya, UU No.24/2009 yaang lebih menekankan dan memerhatikan penggunaan bahasa Indonesia dibandingkan dengan BD. Begitu juga PP No.63/2019 sehingga praktis tinggal menunggu lonceng kematian bagi $\mathrm{BD}$.

Dari 700-an lebih BD atau bahasa lokal yang ada di Indonesia, salah satunya adalah bahasa Jawa. Dari jumlah bahasa lokal/BD tersebut menurut catatan Badan Bahasa dalam kurun waktu tahun 2011 s.d. 2018 dari 71 bahasa yang disampling terdapat 19 $\mathrm{BD}$ dikategorikan aman, $11 \mathrm{BD}$ punah, 4 kritis kondisinya, dan 19 BD terancam punah (Kompas, 21 Februari 2018). Pertanyaannya adalah apakah bahasa Jawa akan bernasib sama dengan bahasa-bahasa daerah yang telah punah? Jika itu terjadi, maka peradaban Jawa, kebudayaan Jawa, artefak Jawa, filosuf Jawa, pujangga Jawa, seniman Jawa, tradisi Jawa, kearifan lokal Jawa akan ikut terkubur. Akankah itu terjadi? Penelitian ini akan menelusurinya pada para kaum perempuan Jawa pesisir dan pedalaman. Dalam penelitian ini dihipotesiskan bahwa ibu/kaum perempuan merupakan penyimpan, pelanggeng, dan penyemai budaya/ bahasa yang paling gigih. Jika itu benar, lalu pertanyaan berikutnya adalah bagaimanakah cara perempuan mempertahankan bahasa Jawa? Lalu, lewat cara apa saja kaum perempuan dalam mempertahankan bahasa Jawa dari ancaman bahasa (dan budaya) Indonesia dan bahasa Inggris (dan budaya global). Pertanyaan-pertanyaan itulah yang akan dicari jawabnya dalam penelitian ini. 


\section{METODE}

Populasi penelitian ini adalah seluruh kaum perempuan di Kabupaten Rembang, tetapi karena besarnya jumlah populasi maka diambil sampel. Sampel diambil dari Rembang kota dan Rembang desa dengan asumsi kedua wilayah tersebbut mewakili karakteristik perempuan Rembang. Lalu, pengumpulan data dilakukan dengan langkah-langkah (a) melakukan studi pendahuluan untuk memahami karateristik secara umum sampel sasaran, (b) mengidentikasi kelompok/ kaum perempuan pesisiran yang dinilai memenuhi persyaratan sebagai sampel penelitian. Setelah kedua langkah di atas dilakukan, langkah selanjutnya adalah

(a) menyusun instrumen penelitian, (b) uji coba instrumen penelitian. Setelah itu, langkah berikutnya adalah melakukan (a) penyebaran angket, (b) melakukan observasi nonpartisipan, (c) wawancara mendalam dengan sejumlah informan/tokoh masyarakat (perempuan) dengan metode snowball. Selain langkah-langkah di atas, penelitianinijuga menggunakan sumber data sekunder, yaitu berupa data hasil penelitian yang relevan dengan topik penelitian ini. Misal, hasil/laporan penelitian tentang pemilihan bahasa, sikap bahasa, pergeseran bahasa, dan atau pemertahanan bahasa.

Data dianalisis dengan metode kualitatif dan kuantitatif. Metode kualitatif terutama untuk menganalisis data dari hasil wawancara, sedangkan metode kuantitatif dilakukan untuk menganalisis dari sumber data berupa angket.

\section{HASIL DAN PEMBAHASAN Hasil}

Berikut data yang telah diperoleh di lapangan yang disajikan dalam bentuk grafik (bola) seperti di bawah ini.

\section{Rembang Kota}

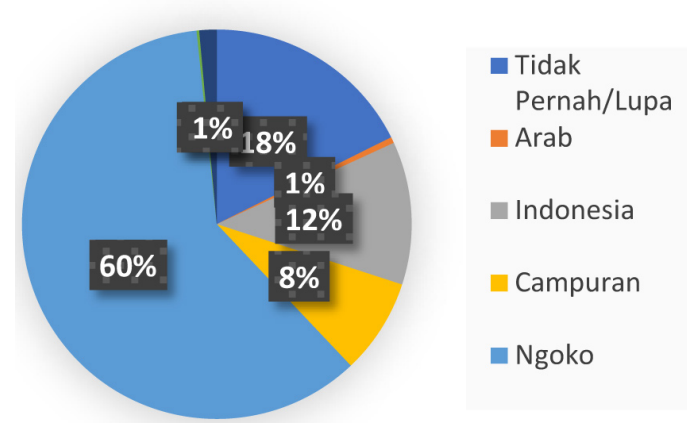

\section{Gambar 1. Grafik Pola Penggunaan Bahasa di Rembang Kota}

Berdasarkan hasil analisis data di Rembang Kota diperoleh data penggunaan bahasa Jawa ngoko masih paling banyak digunakan para kaum perempuan, yaitu sebanyak $60 \%$, lalu 18\% menjawab lupa, (bahasa yang digunakan dalam mimpi), $12 \%$ menggunakan bahasa Indonesia, $8 \%$ menggunakan bahasa campuran (bahasa Indonesia dan bahasa Jawa), 1\% menggunakan bahasa krama inggil dan bahasa Arab, 1\% menggunakan bahasa krama.

\section{Rembang Desa}

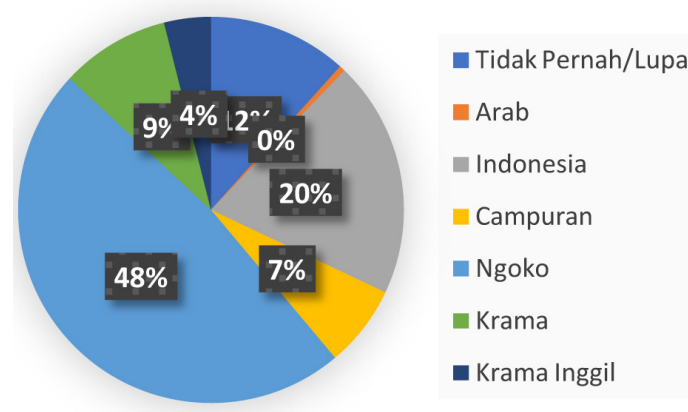

Gambar 2. Grafik Pola Penggunaan Bahasa di Rembang Desa 
Grafik 2 menggambarkan hasil analisis data di daerah Rembang Desa. Dari grafik 2 di atas pula diketahui data penggunaan bahasa Jawa ngoko masih paling banyak digunakan oleh kaum perempuan pesisir, yaitu sebanyak $48 \%$, lalu 20\% menggunakan bahasa Indonesia, 9\% menggunakan bahasa krama, $7 \%$ menggunakan bahasa campuran, 4\% menggunakan bahasa krama inggil dan $0 \%$ menggunakan bahasa Arab, dan $12 \%$ menjawab lupa.

\section{PEMBAHASAN}

Persoalan Pemilihan Bahasa Jawa Kaum Perempuan di Wilayah Rembang

Berikut disajikan situasi kebahasaan di Indonesia yang dapat ditelusuri.
Pertama, karya Hamam Riza yang berjudul "Indigenous Languages of Indonesia: Creating Language Resources for Language Preservation" yang menjelaskan bahwa tidak sulit untuk mendapatkan gambaran betapa beragamnya bahasa di Indonesia. Menurutnya, terdapat 726 bahasa (ada yang menyebut 746) di Indonesia menjadikannya dunia yang paling beragam kedua, setelah Papua Nugini yang memiliki 823 bahasa lokal ( lihat Hamam, 2008). Indonesia juga memiliki rasio bahasa yang tinggi terhadap penutur di setiap wilayah utama di Indonesia (lihat Gambar 1 di bawah ini).

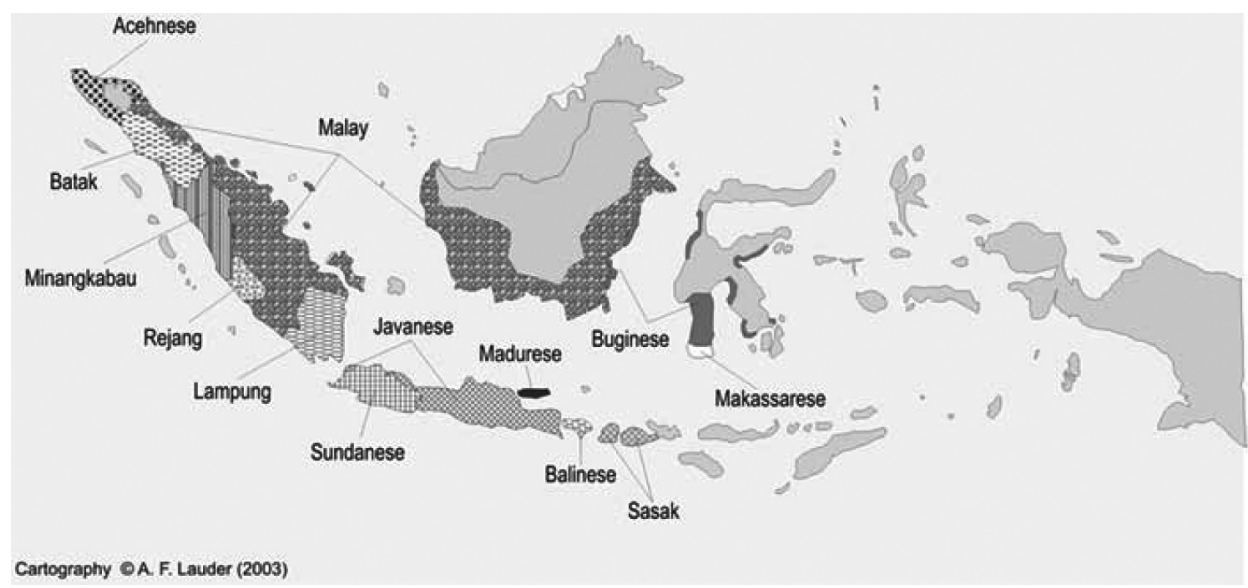

Gambar 1. Persebaran penutur bahasa di setiap wilayah di Indonesia

Lebih lanjut dikatakan oleh Hamam (2008) dengan mengutip berbagai sumber bahwa bahasa Indonesia adalah bagian dari situasi linguistik yang kompleks yang umumnya dilihat terdiri atas tiga kategori: bahasa Indonesia, bahasa asli daerah, dan bahasa asing. Di antara 736 bahasa yang ada di Indonesia di Indonesia, tercatat 13 bahasa yang memiliki jumlah penutur 1 juta lebih. Bahasa-bahasa terbebut adalah bahasa Jawa (75.200.000 penutur), Sunda (27.000.000), Melayu (20.000.000), Madura (13.694.000), Minangkabau (6.500.000), Batak (5.150.000), Bugis (4.000.000), Bali (3.800.000), orang Bali (3.000.000), orang Sasak (2.100.000), Makasar (1.600.000), Lampung 
(1.500.000), dan Rejang (1.000.000). Sementara, 713 bahasa yang tersisa memiliki populasi total hanya 41,4 juta penutur, dan sebagian besar memiliki penutur yang sangat sedikit. Misalnya, 386 bahasa dituturkan oleh 5.000 atau kurang; 233 memiliki 1.000 pembicara atau kurang; 169 bahasa memiliki 500 penutur atau kurang; dan 52 memiliki 100 atau kurang.

Di antara bahasa-bahasa daerah yang ada di Indonesia, bahasa Jawa merupakan bahasa daerah yang jumlah penuturnya paling banyak (75.200.000). Hal itu, juga tercermin pada data pada grafik 1 yang diperoleh dari lapangan di Rembang Kota dalam domain rumah, ketetanggaan, dan domain sosial seperti pertemuan RT, pertemuan RW, pengajian, dawis (dasa wisma). Kaum perempuan Jawa pesisir berdasarkan data melalui angket dan observasi yang diperoleh, menunjukkan bahasa Jawa masih tergolong dominan penggunaannya $(60 \%)$ meski dalam hal ini bahasa Jawa ragam ngoko. Ragam bahasa yang memiliki tingkat kesopanan paling rendah.

Ketika suatu bahasa mulai tidak digunakan lagi maka Bahasa tersebut mengalami kepunahan. Rata-rata bahasa hilang/punah setiap dua minggu di seluruh dunia. Implikasinya, ketika sebuah bahasa lisan hilang/ punah, dibutuhkan semua pengetahuan yang dimiliki orang-orang dan ketika pembicara terakhir meninggal, kemungkinan tidak ada jejak sama sekali dari keberadaan mereka. Tidak akan ada artefak atau catatan fisik untuk merekonstruksi bahasa atau pengetahuan yang disandikannya. Karena setiap bahasa mati, kita kehilangan data untukfilsuf, antropolog, folklorist, sejarawan, psikolog, ahli bahasa, dan penulis.

Hamam (2008) mengakui, di Indonesia, selama beberapa tahun terakhir, telah ada peningkatan kesadaran tentang pentingnya sumber daya korpus dalam pelestarian bahasa. Ketika para pemimpin regional mulai mempertimbangkan implikasi dari kehilangan aset asli mereka, perhatian yang cukup besar sedang dibantu untuk peran yang bisa dimainkan oleh korpus dan sumber daya leksikal. Misalnya, yang dilakukan Masyarakat Linguistik Indonesia (MLI) dengan bekerja sama dengan sejumlah lembaga, organisasi, dan perusahaan melakukan pemetaan bahasa-bahasa Nusantara. Menurutnya, saat ini sedang dalam proses pemetaan bahasa tertulis asli Indonesia (540 bahasa).

Lebih jauh Hamam juga menyatakan bahwa budaya dan bahasa adalah hak asasi manusia yang mendasar. Oleh karena itu, menjadi hak dan kewajiban kita untuk melestarikan dan mengembangkannya. Dan itu, lebih merupakan pilihan etis, bukan pilihan ilmiah. Menurutnya, selama ini kurangnya kepedulian dan kelambanan terhadap budaya dan bahasa. Selain itu, penelitian yang hanya mendokumentasikan bahasa yang terancam punah, tetapi tidak melakukan apa pun untuk membantu masyarakat bahasa adalah seperti fotografer yang mengambil foto seseorang dalam kesulitan, tetapi tidak melakukan apa pun untuk membantu mereka.

Gejala seperti di atas juga menimpa pada masyarakat kita termasuk masyarakat Rembang. Akibatnya, banyak dikeluhkan tentang eksistensi 
bahasa daerah, termasuk bahasa Jawa mulai tergeser/terancam. Indikasi bahasa Jawa mulai tergeser oleh bahasa Indonesia sudah semakin tampak dari hari ke hari. Hal ini, selaras dengan apa yang dinyatakan oleh Trudgill (2002: 138) bahwa dalam proses pengalihan bahasa, penutur asli dari suatu bahasa (baca: bahasa Jawa) akan beralih ke bahasa-bahasa yang lain (baca: bahasa Indonesia) melalui suatu proses yang disebut kedwibahasaan untuk mengadopsi bahasa-bahasa tersebut secara bertahap. Pengalihan bahasa dilakukan oleh penutur karena beberapa alasan dan proses pengalihannya akan mematikan bahasa (baca: bahasa Jawa ragam krama) sebelumnya secara pasti. Jika penutur mengubah atau mengalihkan bahasa mereka secara penuh ke bahasa yang baru, dalam kasus ini, bahasa baru telah membunuh bahasa sebelumnya. Kondisi semacam ini bisa diartikan sebagai pembunuhan bahasa. Contoh, bahasa Sanskerta dulu digunakan di Jawa dan sekarang telah punah. Kini, bahasa ini hanya ditemukan di literatur lama atau tulisantulisan di perpustakaan. Kematian bahasa-bahasa juga terjadi di beberapa negara lain seperti kematian Cornish, Dalmatian, Livonian dan Manx. Ada juga beberapa bahasa yang sedang hampir punah, seperti bahasa Jerman di Perancis, bahasa Italia dan Denmark di Perancis, dan bahasa Latin di Albania. Sementara itu, Zubaidah (2014) mencatat bahwa kebanyakan bahasabahasa yang terancam dan yang telah punah adalah bahasa-bahasa daerah yang ditemukan di provinsi-provinsi Indonesia seperti Kalimantan, Papua, Sulawesi, Maluku, dan Sumatera. Ia menunjukkan bahwa bahasa-bahasa daerah seperti Mapia, Tandia, Bonerif, dan Saponi (digunakan di Papua) dan Punan Merah dan Kareho Uheng (digunakan di Kalimantan) telah musnah, sementara Lom (digunakan di Sumatera), Budong-budong, Dampai, Bahonsai dan Baras (digunakan di Sulawesi), Hoti dan Kayeli (digunakan di Maluku) ada dalam keadaan sekarat dan diprediksi akan segera menghilang.

Berdasarkan grafik 1, pemilihan bahasa Indonesia menduduki urutan kedua (12\%). Hal ini menunjukkan telah terjadi "kebocoran" diglosia sekaligus ancaman terhadap eksistensi bahasa Jawa. Bahasa Indonesia sudah mengancam penutur jati Jawa terutama, menurut pengamatan dan wawancara, melanda pada perempuan pesisir Rembang yang berusia 30 tahunan. Mereka (yang berusia muda tersebut) ketika berbicara dengan anakanaknya pun sudah menggunakan bahasa Indonesia. Kondisi ini diperkuat pada kalangan anak-anak (usia 7 tahunan) yang menggunakan bahasa Indonesia ketika berbincang, bermain, dan bercanda dengan sesama temannya. Selain itu, ditemukan juga pola pemilihan bahasa campuran (baha Jawa dan bahasa Indonesia) sebanyak $12 \%$. Para responden pada kelompok ini sedang mengalami pergeseran bahasa. Semula masih sebagai multilingual/ dwibahasa (sebagai penutur bahasa Jawa dan bahasa Indonesia), tetapi secara perlahan sedang menuju ke monolingual (bahasa Indonesia). Pilihan untuk menjadi monolingual (sebagai penutur bahasa Indonesia) karena bahasa Indonesia dinilai tidak rumit, lebih bergengsi, bahasa "zaman now", secara masif digunakan 
dalam berbagai pranata sosial. Selain secara masif, bahasa Indonesia juga secara sistematis dan terstruktur memungkinkan untuk dipilih oleh penutur (seluruh) Indonesia sebagai alat ekspresi dan alat komunikasi dengan sesama karena secara politis Pemerintah (pusat) "memaksa" untuk menggunakan bahasa Indonesia lewat PP no 63/2019 dan UU No.24/2009. Pada produk politik (bahasa) tersebut bahasa Indonesia mendapat porsi dan perhatian yang sangat besar untuk berkembang dan dikembangkan, sedangkan bahasa daerah (termasuk bahasa Jawa) "dibiarkan" untuk tidak berkembang dan "dikerdilkan".

Sementara itu, dari temuan sebagaimana tampak pada grafik 2, bahasa Jawa ragam ngoko masih cukup dominan (48\%) digunakan seharihari oleh kaum perempuan pesisir di wilayah Rembang desa (sebagai titik pengamatan penelitian ini) disusul penggunaan/ pemilihan bahasa Indonesia sebagai alat komunikasinya. Temuan ini berbeda dan menarik jika dibandingkan dengan kaum perempuan pesisir yang tinggal di wilayah Rembang kota (yang hanya 12\%). Dari temuan ini diduga disebabkan oleh paling tidak dua hal, yaitu (1) kaum perempuan pesisir Rembang desa sedang melalukan mobilitas vertikal. Agar tidak dianggap "nDesa" kaum perempuan desa di Rembang desa sedang berupaya mengidentifikasikan dirinya lewat pilihan bahasanya, yaitu bahasa Indonesia. Sebab, bahasa Indonesia dinilai sebagai "bahasa kota"; yang ke(2) strata/kasta bahasa Indonesia dinilai lebih tinggi dan lebih bergengsi dalam pandangan kaum perempuan Rembang desa jika dibandingkan dengan bahasa Jawa.
Selain 3 pola pemilihan bahasa (bahasa Jawa ngoko, bahasa Indonesia, dan bahasa campuran) pada perempuan Jawa Rembang kota, juga ditemukan pola pemilihan bahasa Jawa ragam krama dan krama inggil masing-masing $1 \%$. Temuan ini menggembirakan, tetapi sekaligus menyedihkan. Dikatakan menggembirakan karena ternayata bahasa Jawa ragam krama (madya dan inggil) masih dituturkan oleh perempuan Rembang. Akan tetapi, juga memrihatinkan karena bahasa Jawa ragam krama (madya dan inggil) sudah hampir punah. Ironis, bahasa Jawa ragam krama (madya dan inggil) mati di lumbung induknya sendiri (yaitu penutur Jawa). Padahal di dalam bahasa Jawa ragam krama tersebut tersimpan nilai-nilai filosofis dan didaktis yang mendalam dan tak ternilai harganya.

Temuan berikutnya pada perempuan Jawa di wilayah Rembang desa adalah pola penggunaan bahasa Jawa ragam krama sebesar 9\% dan krama inggil sebesar 4\% (jika digabung total $13 \%$ ). Angkainisangatberbedadengantemuan pada kaum perempuan Rembang kota yang hanya $1 \%$ (jika digabung krama madya dan krama inggil total $2 \%$ ). Angka ini menggambarkan bahwa pemertahanan bahasa Jawa ragam krama kaum perempuan Rembang desa jauh lebih baik dibandingkan dengan kaum perempuan Rembang kota. Hal itu juga dapat dimakanai bahwa nilai-nilai kesantunan, didaktis, dan filosofis masyarakat, khususnya kaum perempuan Rembang desa masih lebih baik dibandingkan dengan masyarakat/ perempuan Rembang kota.

Dalam penelitian ini ditemukan adanya responden di Rembang kota 
yangmenjawabmemilih/menggunakan bahasa Arab sebanyak 1\%. Dari hasil pengamatan di lapangan penutur bahasa Arab ini adalah tokoh agama, sehingga wajar jika menggunakan bahasa Arab. Akan tetapi, bahasa Arab (ini) digunakan terutama pada saat ceramah agama, sehingga belum dapat dikatakan sebagai bahasa seharihari. Penelitian ini juga menemukan responden yang menjawab lupa (18\%) bahasa yang digunakan dalam mimpinya. Pertanyaan ini dimaksudkan untuk menggali arus bawah sadar para responden. Responden kelompok ini menyatakan lupa, tidak ingat, tidak pernah bermimpi. Akan tetapi, jika melihat angka persentasenya dapat diduga (bawah sadar) responden kelompok ini menggunakan bahasa Indonesia dan atau bahasa campuran (yang jumlah persentasenya 20\%). Tentu interpretasi ini perlu dibuktikkan di lapangan.

Pola pemilihan bahasa yang ke-4 (pola 1: bahasa Jawa ngoko, pola 2: bahasa Indonesia, pola 3: bahasa Jawa ragam krama) adalah penggunaan bahasa campuran yang mencapai angka $7 \%$ di wilayah Rembang desa. Temuan ini sedikit berbeda dengan perempuan Rembang kota yang mencapaai $8 \%$. Dalam kasus ini dapat diinterpretasikan bahwa gejala terjadinya pergeseran bahasa antara perempuan Rembang desa dan kota relatif sama.

Temuan berikutnya, yaitu responden diRembangdesalupa (12\%)bahasa yang digunakan ketika bermimpi. Angka ini lebih kecil dibandingkan dengan angka pada perempuan Rembang kota (18\%). Temuan di wilayah pesisir Rembang adalah penggunaan bahasa Arab sebesar $0 \%$. Hal ini dapat diartikan bahasa
Arab tidak populer/tidak dikenal oleh perempuan Rembang desa.

\section{Model Pemertahanan Bahasa Jawa di Rembang}

Ada bermacam-macam faktor yang menyebabkan punahnya bahasa daerah/bahasa lokal. Menurut hasil penelitian sebelumnya, yang paling utama adalah berkembangnya sikap anak-anak muda Indonesia yang membanggakan diri mereka sebagai suatu masyakarakat modern dan sikap malas pemerintah terhadap pelestarian bahasa-bahasa daerah (lihat, Suharyo, 2017). Penelitian terhadap penggunaan bahasa-bahasa daerah di Indonesia pada generasi muda menunjukkan adanya suatu temuan yang agak mengejutkan bahwa anak-anak muda tidak menggunakan bahasa-bahasa daerah mereka di dalam keluarga karena alasan bahwa menggunakan bahasa daerah dianggap konservatif dan primitif (cf Suharyo, 2018). Dan kemampuan berbicara dalam bahasa Indonesia dianggap lebih prestisius daripada bahasa daerah. Terlebih lagi, kemampuan berbicara bahasa Inggris menjanjikan masa depan karir yang lebih baik di mata dunia. Faktor kedua, sikap "malas" pemerintah adalah salah satu faktor lain yang menyebabkan hilangnya bahasa-bahasa daerah di negara ini. Meskipun otonomi daerah diberikan oleh pemerintah pusat kepada semua provinsi di Indonesia, sistem pendidikan masih sangat terpusat. Sebagai contoh, kurikulum nasional masih dipaksakan kepada semua provinsi hampir tanpa pengecualian; sedangkan untuk kurikulum pengajaran bahasa adalah bahasa nasional (bahasa Indonesia) dan bahasa asing (biasanya 
bahasa Inggris) yang diberikan hak istimewa. Buku-buku sekolah dan sistem evaluasi nasional masih ditulis dalam bahasa Indonesia dan sangat jarang ditulis dalam bahasa daerah para murid. Terlebih lagi, buku-buku berbahasa Inggris diimpor dan didistribusikan tuntuk memenuhi permintaan pengajaran bahasa Inggris di berbagai provinsi. Sangat jelas bahwa semua hal ini pada akhirnya akan menyebabkan termarjinalisasikannya bahasa-bahasa daerah di Indonesia. Terkait temuan ini, menarikuntukdipertimbangkantemuan Sugiarto (2014) yang menyimpulkan bahwa sudah sangat mendesak untuk mempromosikan pendidikan berbasis bahasa-ibu.

Dorongan menuju monolingualisme di dalam konteks bahasa Indonesia terbukti lewat antusiasme pemerintah mendorong penggunaan bahasa resmi dalam pendidikan dan melalui menjamurmnya pemasaran bahasa Inggris untuk pendidikan anak usia dini, pemberlakuan peraturan yang mewajibkan penggunaan bahasa Inggris di banyak sekolah di Indonesia, dan kecenderungan yang kuat dari orang tua untuk memasukkan anaknya ke sekolah "international" yang menjadikan bahasa Inggris menjadi medium utama untuk pembelajaran (Sugiharto, 2014). Kuatnya pemerintah terhadap upaya menomorsatukan bahasa Indonesia tampak pada PP No.63/2019 dan UU No. 24/2009.

Langkah yang dapat dilakukan untuk "membendung" dominasi bahasa Indonesia dan bahasa Inggris adalah menjadikan pendidikan bahasa. Hal ini, misalnya, dapat dilakukan dengan lebih efektif jika pengajaran bahasa daerah lebih dari sekedar konteks lokal, namun juga harus menjadi suatu subjek wajib bagi semua murid.

Widianto (2018) dalam hasil penelitian yang berjudul "Pemertahanan Bahasa Daerah melalui Pembelajaran dan Kegiatan di Sekolah" mengungkapkan bahwa pemertahanan (maintenance) merupakan fenomena yang hadir secara bersamaan dengan adanya pergeseran bahasa (language shift). Pemertahanan dan pergeseran bahasa bagaikan dua sisi mata uang. Dalam kajian sosiolinguistik, keduanya tidak dapat dipisahkan. Indonesia memiliki beragam bahasa daerah yang perlu dipertahankan dan dijaga. Salah satu pemertahanan bahasa daerah dapat dilakukan melalui pendidikan. Menurutnya, pemertahanan bahasa daerah tersebut dapat dilakukan melalui 1) pembelajaran; 2) kegiatan komunitas/ekstrakurikuler; dan 3) alat komunikasi wajib pada hari tertentu. Hal itu berfungsi sebagai upaya 1) mencegah pergeseran dan kepunahan bahasa daerah; 2) mempersiapkan penutur bahasa daerah di masa depan; dan 3) melestarikan budaya bangsa. Menurutnya, pemertahanan bahasa daerah melalui pembelajaran dan kegiatan di sekolah memiliki implikasi positif. Artinya, pemertahanan bahasa daerah berjalan dengan maksimal dalam ranah pendidikan. Di samping itu, pendidikan juga merupakan komponen penting yang digunakan untuk melestarikan bahasa dan budaya. Oleh sebab itu, pemertahanan bahasa memiliki peluang untuk dilakukan dalam ranah pendidikan. Lebih jauh dikatakan, dalam ranah pendidikan, pemertahanan bahasa daerah dilakukan melalui pembelajaran dan kegiatan di sekolah. Pemertahanan 
bahasa daerah perlu digalakkan untuk membendung pergeseran bahasa yang kian hari terus berjalan dan semakin mengkhawatirkan.

Hasil penelitian Wilian (2010) menunjukkan bahwa BSs (Bahasa Sasak) di Lombok, sebagai bahasa ibu masih akan tetap bertahan karena masih digunakan di ranah keluarga, ketetanggaan, kekerabatan, ranah-ranah tertentu, dan kestabilan kedwibahasaaan kedwibahasawanan masyarakat masih akan tetap terjaga. Meskipun ada kecenderungan bahwa makin muda kelompok usia responden tampak makin besar rerata pilihan bahasanya. Namun, hal itu hanya menunjukkan kekerapan interaksi dalam berbagai situasi interaksi, yang memang merupakan fenomena umum dan wajar terjadi dalam masyarakat diglosik yang disebabkan oleh faktorfaktor sosial-psikologis yang terjadi di antara para petutur. Hal itu masih jauh dari kecenderungan pergeseran menuju masyarakat monolingual BI, seperti yang menimpa bahasa Kaili di kota Palu

Secara teoretis, dengan mengutip bergabai sumber dan peneliti lainnya, Wilian (2010) mengemukakan bahwa berdasarkan pengalaman-pengalaman bahasa-bahasa lain di dunia yang mengalami keterancaman seperti halnya juga bahasa Lampung di Indonesia (Wilian mengutip Gunarwan 1994), bahasa Arvanitika, bahasa orang keturunan Albania di Yunani (mengutip Trudgill dan Tzavaras di dalam Giles, 1972) atau bahasa Hungaria di desa Oberwart perbatasan Austria-Jerman (Wilian mengutip Gal, 1979), bahasa yang terancam tergeser itu adalah bahasa yang sudah tidak lagi dipakai oleh generasi mudanya di rumah bersama keluarganya, tinggal hanya dipakai oleh generasi-generasi tua. Lebih jauh Wilian mengatakan bahwa secara tipologis, dengan mengutip pendapat Krauss (1992) yang mengelompokkan bahasa-bahasa di dunia ke dalam tiga tipe (bahasa yang punah, terancam punah, dan masih aman), maka BSs masih tergolong aman, bahkan mungkin sangat aman, karena secara demografis BSs masih memiliki penutur yang cukup besar dan didukungoleh pola pemakaian bahasa di rumah yang dapat menjamin terjadinya pengalihan bahasa-ibu antargenerasi (intergenerationalmothertonguecontinuity). Di samping itu, pemakaian BSs dalam dunia pendidikan mendapat dukungan dari pemerintah, yang dibuktikan dengan diajarkannya bahasa daerah sebagi muatan lokal di sekolah-sekolah, serta dilindungi pula oleh undangundang sebagai cagar budaya bangsa.

Terkait dengan hasil penelitian Wilian (2010), kondisi kebahasaan di Rembang sedikit berbeda. Hasil penelitian di Rembang menunjukkan bahwa bahasa Jawa ragam ngoko masih tergolong aman, tetapi untuk bahasa Jawa ragam krama terancam punah. Lebih lanjut Wilian (2010) menjelaskan bahwa pola-pola kedwibahasaan masyarakat masih dalam keadaan stabil, sama halnya dengan situasi kebahasaan di Rembang. Hal ini mengisyaratkan bahwa ranah-ranah pemakaian bahasa masih berjalan sebagaimana adanya sesuai fungsi masing-masing bahasa. Kedwibahasaan yang stabil mengindikasikan bahwa penguasaan terhadap kedua bahasa (BSs dan BI) sama, sehingga dapat dipakai secara bergiliran tanpa menyebabkan 
dislokasi secara struktural. Dengan telah mantapnya B1 (BSs) mereka sebelum B2 (BI) diharapkan dapat menjaga kestabilan pemakaian kedua bahasa sesuai dengan fungsi dan ranah masing-masing, sehingga dengan begitu istilah bahasa $\mathrm{T}$ dan bahasa $\mathrm{R}$ dapat hidup secara berdampingan, tanpa yang satu merasa terancam oleh yang lain. Kecenderungan pemakaian BI sebagai bahasa ibu menggantikan BSs di rumah masih sebatas yang dapat ditolerir. Kondisi ini juga tercermin pada masyarakat di Rembang. Dan soal kekhawatiran generasi tua bahwa generasi muda cenderungmenggunakan BI jika diajak bicara hanya merupakan gejala psikologis kebahasaan yang juga terjadi pada masyarakat penutur bahasa lain yang mengenal tingkatan bahasa sepertibahasa Jawa. Berdasarkan survei hanya $4,28 \%$ responden $(\mathrm{N}=911)$ yang benar-benar menggunakan BI sebagai bahasa ibu sejak kecil. Meskipun secara keseluruhan rata-rata generasi muda menggunakan BI sama seringnya dengan BSs di luar rumah, hal itu hanya merupakan gejala yang umum terjadi pada masyarakat bilingual. Selaras dengan temuan Wilian (2010) bahasa Jawa ragam ngoko akan tetap bertahan, tetapi untuk bahasa Jawa ragam krama akan segera punah. Hal itu, tampaknya karena dalam BSs tidak dikenal ragam yang hierarkis sifatnya, sedangkan pada bahasa Jawa dikenal adanya beberapa ragam (ngoko dan krama termasuk variannya) yang dinilai dan dirasakan cukup rumit baik sebagai bahasa maupun penggunaannya.

Dari artikel Teuku Alamsyah, Rostina Taib, Azwardi, Muhammad Idham.2011. pada Jurnal Pendidikan Bahasa Melayu (Malay Language
Journal Education) (MyLEJ), Nanggroe Aceh Darussalam dengan judul "Pemilihan Bahasa Indonesia sebagai Bahasa Pertama Anak dalam Keluarga Masyarakat Aceh Penutur Bahasa Aceh di Naggroe Aceh Darussalam" menyimpulkan bahwa para penutur masyarakat Aceh secara umum dikelompokkan menjadi (1) kurang mampu berbahasa bahasa Indonesia karenat takut salah dan (2) terdapat sekelompok masyarakat yang dapat berbahasa Indonesia, tetapi sangat terbatas. Sebab, dalam praktiknya mereka sering menggunakan bahasa campuran (Indonesia dan Aceh). Jadi terdapat situasi alih kode dan campur kode.

Melihat temuan lapangan sebagaimana dipaparkan di atas, pemertahanan kaum perempuan Rembang baik Rembang kota maupun Rembang desa lebih dominan pada pemertahanan bahasa Jawa ragam ngoko. Jika bahasa Jawa ragam ngoko dinilai sebagai cerminan kesetaraan/ keegaliteran, maka perempuan Rembang kota lebih egaliter (60\%) dibandingkan dengan perempuan Rembang desa (48\%). Sementara itu, pemertahanan pada level bahasa Jawa ragam krama (madya/inggil); pemertahanan kaum perempuan Rembang desa (13\%) lebih tinggi/ kuat dibandingkan dengan perempuan Rembang kota (2\%). Jika bahasa Jawa ragam krama dimaknai (secara budaya) sebagai indikator 'kesantunan', maka perempuan Rembang desa lebih santun dibanding perempuan Rembang kota.

Upaya-upaya masyarakatkhususnya perempuan Rembang baik Rembang kota maupun Rembang desa dalam rangka mempertahankan bahasa Jawa 
dilakukan melalui (1) jalur pendidikan, (2) jalur budaya/seni, (3) jalur tradisi, (4) jalur pendidikan nonformal, dan (5) jalur ke-tokoh-an/keteladanan. Pada jalur pendidikan upaya yang dilakukan adalah melalui (terutama) pada PAUD. Dengan kreatif dan menarik, guru menggunakan APE (alat peraga edukasi) berupa CD (pembelajaran bahasa Jawa secara tematik). Begitu juga pada pendidikan tingkat SD dan SMP meski belum maksimal karena bahasa Jawa ditempatkan sebagai muatan lokal dalam kurikulum. Melalui jalur budaya dilakukan melalui berbagai lomba dan latihan wayang kulit yang bahasa pengantarnya menggunakan bahasa Jawa. Untuk jalur tradisi, di Rembang secara rutin diadakan sedekah laut, maulidan, dll. Untuk jalur pendidikan nonformal, misalnya melalui latihan nari, gamelan, dll. Sementara itu, jalur keteladanan dilakukan oleh tokoh-tokoh masyarakat (tokoh agama dan tokoh masyarakat) dalam kapasitasnya sebagai dai/tokoh seni yang selalu menggunakan bahasa Jawa dalam aktivitasnya (misalnya, saat tausiah, ceramah agama, melatih gamelan, melatih tari). Di samping itu, upaya pemertahanan bahasa Jawa juga difasilitasi oleh pemerintah setempat melalui jalur lomba seni/budaya yang diselenggarakan secara reguler.

\section{SIMPULAN}

Dari uaraian di atas dapat diambil catatan sebagai simpulan. Pertama, kaum perempuan menjadi sosok yang penting dan strategis seabagi pemerihara, pemertahan, dan pengawet, sekaligus sebagai benteng terakhir pemertahanan suatu bahasa. Akan tetapi, dapat juga sebaliknya, jika perempuan tidak berkomitmen, maka dapat diramalkan bahwa suatu bahasa akan ditinggalkan pemakainya. Sebab, di tangan perempuanlah suatu bahasa akan terpelihara ketika kaum peremmpuan menjaganya lewat pengalihan bahasa (ibu) kepada generasi selanjutnya. Kedua, bahasa Jawa di wilayah Rembang baik Rembang Kota maupun Rembang desa yang menjadi titik pengamatan penelitian ini lebih banyak (48\% sampaidengan $60 \%$ )dipilih oleh kaum perempuan pesisir sebagai bahasa sehari-hari di rumah, tetangga, pertemuan dawis, PKK, RW, dan ranah sosial lainnya jika dibandingkan dengan bahasa lainnya (Indonesia, campuran, Arab). Ketiga, bahasa Indonesia sudah mulai digunakan pada ranah rumah baik pada masyarakat, khususnya kaum perempuan Rembang kota maupun Rembang desa dengan angka kisaran $7 \%$ sampai dengan $12 \%$. Degan demikian, khususnya pada ranah rumah telah terjadi "kebocoran" diglosia. Ranah rumah yang "semestinya"/ yang secara klasik digunakan bahasa daerah (dalam hal ini bahasa Jawa) sudah mulai disusupi bahasa Indonesia. Keempat, bahasa lain yang dipilih oleh kaum perempuan pesisir Rembang kota dan Rembang desa adalah bahasa campuran (bahasa Jawa dan bahasa Indonesia). Kelima, bahasa Jawa ragam krama (madya dan inggil) masih digunakan pada masyarakat Rembang khususnya kaum perempuan baik Rembang kota maupun Rembang desa meskipun angkanya kecil (2\% untuk Rembang Kota). Akan tetapi, pada Rembang kota (13\%). Ketujuh, bahasa Arab menjadi pilihan kaum perempuan di Rembang Kota meski angkanya kecil (1\%), tetapi diduga jawaban responden 
dalam konteks in bukan sebagai bahasa sehari-hari. Kedelapan, terdapat sejumlah responden yang menjawab tidak tahu baik responden perempuan Rembang kota maupun Rembang desa (persentasenya $18 \%$ dan 12\%) ketika ditanya bahasa apa yang digunakan ketika bermimpi. Pada temuan diduga ada dua kemungkinan. Kemungkinan pertama, responden benar-benar lupa, atau kemungkinan kedua, responden mengguakan bahasa campuran. Hal ini (terutama untuk perempuan Rembang kota) jika dilihat angka persentasenya dengan bahasa campuran. Akan tetapi, ini baru dugaan. Tentunya, perlu diferivikasi di lapangan. Kesembilan, jika pemnggunaan bahasa Jawa ragam krama dimaknai sebagai indikator kesantunan, maka temuan penelitian ini menujukkan perempuan Rembang desa (13\% yang berbahasa Jawa ragam krama madya/inggil) dinilai lebih santun daripada perempuan Rembang kota $(2 \%)$.

Terkait dengan pemertahanan bahasa dapat disampaikan beberapa catatan. Pertama, bahasa Jawa khususnya ragam krama masih tampak daya pemertahanannya cuku kuat karena didukung oleh $60 \%$ untukperempuan Rembang kota dan 48\% untuk perempuan Rembang desa. Kedua, bahasa Jawa ragam krama di Rembang kota terancam punah karena sampai saat ini hanya didukung oleh $2 \%$ masyarakat pemakainya. Ketiga, bahasa Indonesia sudah mulai mengancam eksistensi bahasa Jawa. Keempat, pada masyarakat Rembang dan lebih khusus lagi perempuan Rembang baik kota maupun desa saat ini tengah terjadi pergeseran bahasa, yaitu dari bahasa Jawa ke bahasa Indonesia. Indikasinya, terlihat dari penggunaan bahasa campuran sebagai bahasa sehariharinya (antara 7\% sampai dengan $12 \%)$.

Selain catatan dan temuan di atas, ada sejumlah upaya untuk mempertahankan bahasa Jawa dari ancaman bahasa Indonesia dan atau bahasa asing. Upaya-upaya yang dilakukan melalui berbagai bidang dan atau berbagai kegiatan. Upaya di bidang pendidikan, misal melalui pembelajaran bahasa Jawa (krama/ngoko) pada PAUD, sekolah dasar, dan sekolah menengah. Upaya dalam pendidikan usia dini (PAUD) diharapkan anak-anak kelak tidak meninggalkan bahasa Jawa sebagai bahasa ibunya. Dalam bidang seni, di Rembang kota atau Rembang desa terdapat tokoh seni yang sangat gigih untuk mengajarkan bahasa Jawa (misalnya, lewat latihan tari, wayang kulit). Dalam bidang agama, para tokoh agama dengan semanggat selalu menggunakan bahasa Jawa dalam menyampaiakn tausiah, khutbah, dll. Masyarakat Rembang kota/desa juga berupaya mempertahankan bahasa Jawa melalui upacara tradisi sedekah laut dan sejenisnya. Adapun upaya yang dilakukan pemerintah (kecamatan/ desa) melalui fasilitasi berbagai lomba seni/tradisi.

\section{UCAPAN TERIMA KASIH}

Penulis artikel menyampaikan ucapan terima kasih dengan tulus kepada Prof. Dr. Heru Susanto seabagai ketua Lembaga Penelitian dan dan Pengabdian Masyarakat saat proposal penelitian ini diajukan. Berkat beliaulah, penulis diberi kesempatan untuk mengembangkan diri, teruatama dalam bidang penelitian sebagai salah 
satu darma perguruan tinggi. Ucapan ayang ditujukan kepada Prof. Dr. Jamari selaku ketua LPPM yang baru. Ucapana terima kasih juga ditujukan kepada Ovin dan Kukuh Wicaksono yang telah banyak membantu mulai dari persiapan penelitian, terjun ke lapangan, mengolah data, sampai pada aspek teknis berupa pengetikan. Ucapan terima kasih juga disampaikan kepada Suryo, Reni, dan L. Prima mahasiswa yang ikut membantu penulis dalam pengambilan data di lapangan sebagai "anggota" tim penliti sebagai field worker dan penginputan data. Begitu juga kepada Dekan Fakultas Ilmu Budaya, Universitas Diponeoro, Semarang yang sekaligus juga seabagai anggota peneliti ucapan terima kasih disampaikan. Terakhir, ucapan terima kasih ditujukan kepada Kemenristek Dikti terutama DRPM(Direktorat Riset dan Pengabdian kepada Masyarakat) yang meloloskan proposal yang penulis usulkan sehingga penelitian ini dapat dilakukan.

\section{DAFTAR PUSTAKA}

Abdelhadi, M. (2018). Language Maintenance Factors: Reflections on The Arabic Language. APIAR (Asia Pacific Institute of Advanced Research, Asia Pacific Journal of Advanced Business and Social Studies), $4(1), \quad 340-351$. DOI: 10.25275/ apjabssv4i1ss9

Alamsyah, T., et.al. (2011). Pemilihan Bahasa Indonesia sebagai Bahasa Pertama Anak dalam Keluarga Masyarakat Aceh Penutur Bahasa AcehdiNanggroeAcehDarussalam. Jurnal Pendidikan Bahasa Melayu, Malay Language Journal Education (MyLEJ), 1(2), 31-44. http://spaj. ukm.my/jpbm/index.php/jpbm/ article/view/28/28.

Gordon, R. G., Jr. ed. (2005). Ethnologue: Languages of the World, Fifteenth Edition. Dallas, Tex.: SIL International.

Hadiati, P. (2013). Pergeseran dan Pemertahanan Bahasa Jawa pada Komunitas Band di Studio Orion Kabupaten Kebumen. Jurnal Pendidikan, Bahasa, Sastra, dan Budaya Jawa, 3(6), 12-17. http:// ejournal.umpwr.ac.id/index.php/ aditya/article/view/763/737.

Kholidah, U. (2015). Pemertahanan Bahasa Jawa pada Interaksi Siswa dan Guru dalam Pembelajaran Kajian Sosiolinguistik di Mts AlHikmah Pasir Demak. Jurnal Ranah, 4(2), 105-114. DOI: https://doi. org/10.26499/rnh.v4i2.27.

Mat Awali, N., et.al. (2013). Pemeliharaan Bahasa Ibu: Pola Pemilihan Bahasa di Perbatasan Malaysia-Thailand" artikel dalam SoLLs.INTEC13: International Conference on KnowledgeInnovation-Excellence: Synergy in Language Research and Practice

Riza, H. (2008). Indigenous Languages of Indonesia: Creating Language Resources forLanguagePreservation. Proceedings of the IJCNLP-08 Workshop on NLP for Less Privileged Language. India: Hyerabad.

Suharyo. (2017). Pemilihan Kode pada Generasi Muda Non-Jawa. Jurnal NUSA, 12(4), 216-226. DOI: https:// doi.org/10.14710/nusa.12.4.216226.

Suharyo. (2018). Nasib Bahasa Jawa dan Bahasa Indonesia dalam Pandangan dan Sikap Bahasa Generasi Muda Jawa. Jurnal NUSA, 13(2), 244- 
255. https://doi.org/10.14710/ nusa.13.2.244-255.

Sugiharto, S. (2014). Urgensi Mempromosikan Pendidikan Berbasis Bahasa Ibu: Sebuah Kasus di Indonesia. The International Journal of Foreign Language Teaching, 10(1)

Syaifudin, A. (2008). Pola Pergeseran Bahasa Jawa pada Masyarakat Wilayah Perbatasan Jawa-Sunda dalam Ranah Keluarga di Losari Kabupaten Brebes. Artikel pada Sosiolinguistik's Blog.

Trudgill, P. (2002). Sociolinguistic Variation and Change. Washington DC: Georgetown Univ. Press.

Widianto, E. (2018). Pemertahanan Bahasa Daerah Melalui Pembelajaran dan Kegiatan di Sekolah. Jurnal Kredo, 1(2), 1-13. https://jurnal.umk.ac.id/index.php/ kredo/article/view/2096/1236.
Wilian, S. (2010). Pemertahanan Bahasa dan Kestabilan Kedwibahasaan pada Penutur Bahasa Sasak di Lombok. Linguistik Indonesia, 28(1), Februari 2010.

Yusmawati, et. al. (2018). Pilihan Bahasa Digunakan 0leh Keluarga Tionghoa di Langsa. Language Literacy: Journal of Linguistics, Literature and Language Teaching, 2(2), 159-166. DOI: https://doi. org/10.30743/11.v2i2.682.

Zubaidah, N. (2014). 50 bahasa daerah terancam punah [50 local languages are in an endangered state]. Sindo News.Com. February 21. 